\title{
UPAYA PENINGKATAN \\ DISIPLIN IBADAH BAGI MURID MADRĀSAH \\ (Studi Deskriptif di Madrāsah Dīniyah Takmiliyah Awalilah Miftahussalam Kota Tegal)
}

\author{
Arvian Indarmawan, ${ }^{*}$ \\ Aam Abdussalam, Wahyu Wibisana \\ Program Studi Ilmu Pendidikan Agama Islam, \\ Fakultas Pendidikan Ilmu Pengetahuan Sosial, Universitas Pendidikan Indonesia \\ *E-mail: arvianindra93@gmail.com
}

\begin{abstract}
ABSTRAK
Penelitian ini berangkat dari pentingnya menanamkan disiplin ibadah pada generasi muda, agar pada masa dewasanya tidak cenderung malas, apatis, bahkan menjadi anti agama, atau sekurang-kurangnya tidak memperdulikan kewajibannya sebagai hamba. Penelitian ini bertempat di Madrāsah Dīniyah Takmiliyah Awaliyah (MDTA) Miftahussalam. Penelitian ini bertujuan untuk mengetahui (1) profil MDTA Miftahussalam Kota Tegal (2) perencanaan peningkatan disiplin ibadah bagi murid di MDTA Miftahussalam Kota Tegal (3) pelaksanaan peningkatan disiplin ibadah bagi murid di MDTA Miftahussalam Kota Tegal (4) hasil peningkatan disiplin ibadah bagi murid di MDTA Miftahussalam Kota Tegal. Penelitian ini menggunakan pendekatan kualitatif dengan metode desktiptif. Pengumpulan data dilakukan melalui observasi, wawancara dan studi dokumen. Proses analisis data dilakukan melalui reduksi data, penyajian data dan verification. Berdasarkan hasil penelitian diperoleh gambaran mengenai perencanaan peningkatan disiplin ibadah bagi murid yang dilakukan oleh kepala madrāsah, ustaż dan mualimah dengan menyesuaikan visi dan misi madrāsah yang kemudian membuat program disiplin ibadah. Dalam pelaksanaan, program disiplin ibadah yang direalisasikan yaitu pembiasaan sebelum kegiatan belajar mengajar dengan membaca Asmāul Ḥusna, Al-Qurān, do'a harian dan șalawāh. Pada ektrsakurikuler pengajian dengan berżikir dan berșalawāh, pada ekstrakurikuler șalāh jama'ah dengan berșalawā̄, șalāh, żikir dan berdo'a. Setiap murid mendapatkan buku Kegiatan Ibadah Șalāh Santri (KISS), Kegiatan Ba'da Magrib (KBM) dan Pembiasaan Akhlaq Santri (PAS) yang mewajibkan murid melaksanakan ibadah yang tercantum di dalamnya. Adapun metode yang digunakan yaitu pembiasaan, demokratis (hukuman dan penghargaan yang bersifat edukatif) dan motivasi. Hasil peningkatan disiplin ibadah bagi murid di MDTA Miftahussalam menunjukkan konsistensi ibadah murid dalam șalāh, żikir, do'a harian dan șalawāh, sedangkan kekurangan dapat dilihat dari sebagian besar murid yang mengaku jarang berżikir dengan membaca Asmāul Ḥusna.
\end{abstract}

Kata Kunci: Disiplin, Ibadah, Murid, Madrasah 


\section{PENDAHULUAN}

Peningkatan mutu pendidikan merupakan sasaran pembangunan di bidang pendidikan nasional dan merupakan bagian integral dari upaya peningkatan kualitas manusia Indonesia secara kaffah (menyeluruh). Pendidikan merupakan masalah yang sangat penting dalam kehidupan manusia, karena dipandang sebagai suatu hal yang harus ada dalam keberlangsungan hidup manusia. Dalam Undang-Undang Sistem Pendidikan Nasional N0. 20 Tahun 2003, disebutkan bahwa pendidikan adalah usaha sadar dan berencana untuk mewujudkan suasana belajar dan proses pembelajaran agar peserta didik secara aktif mengembangkan potensi dirinya untuk memiliki kekuatan spiritual keagamaan, pengendalian diri, kepribadian, kecerdasan, akhlaq mulia, serta keterampilan yang diperlukan dirinya, masyarakat, bangsa dan negara (Sumarya \& Nuryani, 2010, hal. 26).

Allāh memberikan potensi
kepada manusia tidak akan
berkembang dengan sendirinya secara
sempurna tanpa adanya bantuan dari
pihak-pihak lain sekalipun potensi
yang dimilikinya bersifat aktif dan
dinamis. Potensi kemanusiaan itu akan
bergerak terus menerus sesuai dengan
pengaruh yang didatangkan kepadanya.
Hanya intensitas pengaruh itu akan
sangat bervariasi sesuai dengan
kemauan dan kesempatan yang
diperolehnya yang dapat menentukan
pengalaman dan kedewasaan masing-
masing. Maka dari itu, manusia sering
disebut sebagai makhluk yang dapat
dididik dan mendidik atau makhluk
pendidikan (Syahidin, 2009, hal. 23).

Sebagai orang yang beragama Islām, kita harus berusaha untuk menjadi orang yang beriman dan bertaqwa. Sebagaimana disebutkan dalam UUD Distem Pendidikan Nasional No 20. Th. 2003 BAB II Pasal 3 bahwa tujuan dari pendidikan tidak lain untuk membentuk manusia yang beriman, bertaqwa dan berakhlaq mulia. Tujuan dari orang-orang beriman adalah berbakti dan beribadah kepada pencipta-Nya. Beribadah disini berarti mengerjarakan perintah dan meninggalkan larangan Allāh SWT., sehingga sampai pada mengabdikan diri kepada Allāh (taqwa).

Tujuan dari orang-orang beriman adalah berbakti dan beribadah kepada pencipta-Nya. Beribadah disini berarti mengerjarakan perintah dan meninggalkan larangan Allāh SWT., sehingga sampai pada mengabdikan diri kepada Allāh (taqwa). Sebagaimana dalam firman-Nya dalam surat Al-Bāqarah ayat 21:

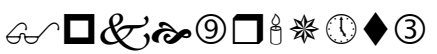

$$
\begin{aligned}
& \downarrow \square \text { Go } \square \text { น०a \& } \\
& \text { 留各 } \square<\text { (9) }
\end{aligned}
$$

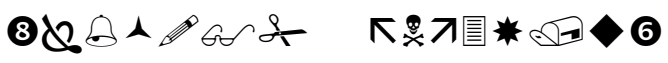

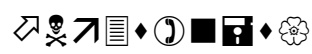

$$
\begin{aligned}
& \text { III है। } \quad x \text { एकी }
\end{aligned}
$$

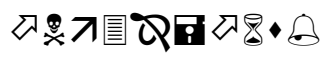

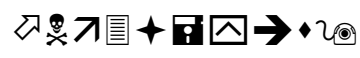

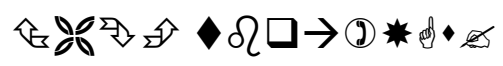


kepadanya tidak terhitung banyaknya. Seharusnya manusia sadar sebagai makhluk yang berakal untuk berterimakasih dengan menjadikan ibadah sebagai sebuah kebutuhan. Tidak akan mengurangi keagungan Tuhan apabila manusia tidak beribadah kepadanya, karena Tuhan tidak butuh manusia untuk menyembahnya, melainkan manusialah yang butuh untuk mengabdi pada-Nya.

Menurut Tim Dosen PAI UPI (2009, hal. 76) kata ibadah dalam bahasa Indonesia berasal dari bahasa 'Arab yaitu ibadah, yang secara etimologi berarti menyembah atau menghamba. Sedangkan secara istilah adalah penghambaaan seorang manusia kepada Allāh untuk dapat mendekatkan diri kepada-Nya sebagai realisasi dari pelaksanaan tugas hidup selaku makhluk yang diciptakan.

Hasbi

Ash-Shiddieqy

menyebutkan bahwa ibadah adalah mengesakan Allāh, menta'zimkan-Nya dengan ta'zim serta menghinakan diri kita, dan menundukkan jiwa kepadaNya (menyembah Allāh sendirinya). Sedangkan ulama akhlaq mengartikan ibadah dengan mengerjakan segala taat badaniyah dan menyelenggarakan segala syariat (hukum). Dan ulama fiqih mengartikan ibadah dengan segala taat yang dikerjakan untuk mencapai keriḍaan Allāh dan mengharap pahala-Nya (Ghazali \& Gunawan, 2015, hal. 181).

Manusia harus sadar bahwa kenikmatan dan karunia yang tercurah kepadanya tidak terhitung banyaknya. Seharusnya manusia sadar sebagai makhluk yang berakal untuk berterimakasih dengan menjadikan ibadah sebagai sebuah kebutuhan.
Tidak akan mengurangi keagungan Tuhan apabila manusia tidak beribadah kepadanya, karena Tuhan tidak butuh manusia untuk menyembahnya, melainkan manusialah yang butuh untuk mengabdi pada-Nya.

Dalam menjalankan ibadah seperti șalāh, membaca Al-Qur’ān, berdo'a dan sebagainya, sikap disiplin sangatlah diperlukan. Seorang muslim yang disiplin dalam melaksanakan ibadah keseharian menandakan rasa hormatnya kepada sang pencipta atas kewajibannya sebagai hamba. Menurut Aftiani (2013, hal. 438) disiplin adalah suatu sikap dan perilaku yang mencerminkan ketaatan dan ketepatan terhadap peraturan, tata tertib, normanorma yang berlaku baik tertulis maupun yang tidak tertulin. Adapun menurut Menurut Hurlock (1978, hal. 82) disiplin berasal dari kata discipline, yaitu seorang yang belajar dari suka rela mengikuti seorang pemimpin. Orang tua dan guru merupakan pemimpin dan anak merupakan murid yang belajar dari mereka cara hidup yang menuju ke hidup yang berguna dan bahagia.

Disiplin akan menunjukkan perilaku taat, patuh, setia, teratur dan tertib. Apabila sudah menyatu pada dirinya, maka sikap atau perbuatan yang dilakukan bukan lagi dirasakan beban, bahkan sebaliknya akan membebani dirinya bilamana ia tidak berbuat (Pujawati, 2016, hal. 230). Adapun menurut Racham (Fiani dkk. 2013, hal. 27) bahwa disiplin penting untuk memberikan dukungan bagi terciptanya perilaku tidak menyimpang, menyesuaikan diri dengan lingkungan, mendorong untuk 
berbuat baik dan belajar hidup dengan kebiasaan yang baik.

Disiplin selalu dianggap perlu untuk perkembangan anak, apalagi dalam urusan ibadah. Dengan mengajarkan disiplin beribadah kepada murid, diharapkan dapat memberikan kesadaran akan pengaturan diri mengenai kewajiban beribadah dan konsisten menjalankan perintah-Nya dan menjauhi laranganNya (istiqamah). Menurut Mulyasa (2010, hal. 108) disiplin bertujuan untuk membantu peserta didik menemukan dirinya dan mengatasi, serta mencegah timbulnya problemproblem disiplin, dan berusaha menciptakan situasi yang menyenangkan bagi kegiatan pembelajaran, sehingga menjadi taat dengan peraturan yang ditetapkan.

Mayoritas penduduk di Indonesia adalah beragama Istām, dan banyak orang tua yang mendambakan putra putrinya kelak dapat bertumbuh dan berkembang menjadi manusia dewasa yang berkepribadian muslim yang beriman, bertaqwa, berakhlaq mulia. Kesadaran masyarakat Islām akan pentingnya hal tersebut menjadikan mereka mencari jalan agar putra-putrinya lebih banyak memperoleh pendidikan agama. Lembaga pendidikan yang berbentuk madrāsah dīniyah bisa menjadi jawaban atas umat Islām untuk putra putrinya dalam memperoleh lebih banyak pendidikan Islām.

Dalam mewujudkan generasi muda yang disiplin beribadah, pastinya memerlukan beberapa upaya. Apabila tidak ada, dikhawatirkan pada masa dewasanya akan cenderung malas, apatis, bahkan menjadi anti agama, atau sekurang-kurangnya tidak memperdulikan kewajibannya sebagai 'abd (hamba). Madrāsah dīniyah sebagai lembaga pendidikan agama memiliki peran penting dalam meningkatkan disiplin ibadah generasi muda, khususnya yang sedikit mendapatkan pendidikan agama di sekolah-sekolah umum.

Madrāsah Dīniyah Takmiliyah Awaliyah (MDTA) Miftahussalam kota Tegal adalah salah satu madrāsah non formal unggulan dan memiliki banyak murid, serta menerapkan beberapa program disiplin ibadah. Sehingga sangat menarik untuk diteliti mengenai upaya yang dilakukannya dalam meningkatkan disiplin ibadah bagi murid.

\section{METODE}

Dalam penelitian ini, peneliti menggunakan desain penelitian case study. Desain case study menurut Nasution (2009, hal. 27-28) case study adalah bentuk penelitian yang mendalam tentang suatu aspek lingkungan sosial termasuk manusia di dalamnya. Case study dapat memberi gambaran tentang keadaan yang ada dan mengenai perkembangan sesuatu, yang dapat dilakukan terhadap seorang individu, kelompok individu, segolongan manusia, lingkungan hidup manusia atau lembaga sosial. Dalam penelitian ini, penelitian terhadap lembaga lendidikan Islam Madrāsah Diniyah Takmiliyah Awaliyah Kota Tegal.

Pendekatan yang peulis gunakan dalam penelitian ini adalah penelitian kualitatif. Menurut Arifin (2014, hal. 29) penelitian kualitatif 
adalah penelitian untuk menjawab permasalahan yang memerlukan pemahaman secara wajar dan alami, sesuai dengan kondisi objektif di lapangan tanpa adanya manipulasi, serta jenis data yang dikumpulkan terutama data kualitatif. Menurut Creswell (2013, hal. 4) penelitian kualitatif melibatkan proses penting, seperti mengajukan pertanyaan dan prosedur, mengumpulkan data yang spesifik dari partisipan, menganalisis data secara induktif dan menafsirkan makna data.

Dalam penelitian ini, peneliti menggunakan metode deskriptif. Menurut Nazir (2011, hal. 55) metode deskriptif adalah metode penelitian untuk membuat gambaran mengenai situasi atau kejadian, sehingga metode ini berkehendak mengadakan akumulasi data dasar berkala.

Adapun yang menjadi partisipan dalam penelitian ini adalah kepala MDTA Miftahussalam Kota Tegal, guru MDTA Miftahussalam Kota Tegal, beberapa murid dan wali murid MDTA Miftahussalam Kota Tegal. Teknik pengumpulan data yang peneliti gunakan diantaranya yaitu wawancara, observasi dan studi dokumen. Untuk keabsahan data, peneliti melakukan triangulasi dan member check. Adapun tahapan analisis data yang peneliti lakukan yaitu mereduksi data dengan memilih data yang dibutuhkan dan dikategorikan dengan coding data hasil reduksi disajikan dalam bentuk narasi yaitu deskripsi suatu peristiwa yang kemudian disimpulkan.

\section{HASIL DAN PEMBAHASAN}

\section{Profil Madrāsah Dīniyah Takmiliyah Awaliyah Miftahussalam Kota Tegal}

Madrāsah ini merupakan madrāsah unggulan di Kota Tegal dengan murid yang mencapai 300 anak lebih, dan mendapatkan sertifikat akreditasi A. Berdirinya MDTA Miftahussalam dilatarbelakangi oleh tidak memungkinkannya kapasitas rumah ustaż Sumar Maktubi (selaku pendiri) karena banyaknya anak-anak yang mengaji di rumahnya. Dengan demikian, warga setempat berinisiatif mendirikan madrāsah dīniyah. Tahun 1974, akhirnya madrāsah dīniyah Miftahussalam dibangun atas tanah wakaf H. Ratim Ghazali dan dana sumbangan dari warga setempat yang terletak di jalan Antasena No. 16 RT 06 RW 02 Kelurahan Slerok Kota Tegal (DOK A. WKM).

$$
\text { MDTA Miftahussalam }
$$

memiliki visi yaitu terwujudnya generasi muslim yang berilmu amaliyah, beramal ilmiah dan berakhlaq karimah (DOK A). Berilmu amaliyah artinya berusaha menjadikan murid memiliki ilmu sebagai landasan dalam melaksanakan amal ibadah dan mengamalkannya. Seseorang yang memiliki ilmu namun tidak mengamalkannya, berarti tidak ada kegunaan dari ilmu yang telah didapatkan.

Sedangkan beramal ilmiyah artinya pihak madrāsah berusaha mewujudkan generasi muslim agar dalam beramal selalu menggunakan ilmunya, tanpa menduga-duga dan mengada-ada. Karena beramal tanpa ilmu, seseorang akan lebih sering 
mendapatkan mudarat dari pada manfaat. Pahitnya, apa yang telah seseorang amalkan itu lebih sering tertolak dan tidak mendapatkan apaapa.

Terakhir adalah mewujudkan generasi muslim yang berakhlaq karimah, karena akhlaq adalah cerminan dari pribadi seseorang mengenai taat atau tidaknya ia kepada Tuhannya. Akhlaq sangat berkaitan dengan ketentuan baik buruk dan benar salah suatu perbuatan. Oleh sebab itu, akhlaq sangatlah berperan penting pada pribadi seseorang dalam pembersihan jiwa, meningkatkan derajat moral kemanusiaan, dan menjauhkan diri dari dorongan untuk berbuat yang dapat merugikan dirinya atau orang lain. Hal tersebut sebagaimana menurut Tim Dosen PAI UPI (2009, hal. 154) dengan ajaran akhlaq, manusia baik akan dibersihkan jiwanya, dingkatkan derajat moral kemanusiaannya, dan dijauhkan dari dorongan dan kecenderungan untuk melakukan tindakan yang merugikan dirinya, atau orang lain yang akhirnya merugikan kemanusiaan itu sendiri.

Sejalan dengan hal tersebut, visi pendidikan dīniyah adalah terwujudnya pendidikan keagamaan yang berkualitas, berdaya saing dan kuat kedudukannya dalam sistem pendidikan nasional sehingga mampu menjadi pusat unggulan Pendidikan Agama Islam dan pengembangan masyarakat dalam rangka pembentukan watak dan kepribadian santri sebagai muslim yang taat dan warga negara yang bertanggung jawab (Departemen Agama Provinsi Jawa Tengah, 2009, hal. 7). Adapun menurut (Usman, 2010, hal. 70) visi sekolah dijadikan sebagai cita-cita bersama warga sekolah yang akan datang, dan mampu memberikan inspirasi, motivasi dan kekuatan pada warga sekolah dan segenap pihak yang berkepentingan.

Selanjutnya adalah misi MDTA Miftahussalam, yaitu :

1. Meningkatkan kemampuan santri dalam membaca AlQur’ān secara baik dan benar sesuai kaidah-kaidah bacaannya (DOK A).

Karena Al-Qur'ān adalah kalam Allah swt., maka membacanya termasuk dalam ibadah. Membacanyapun tidak bisa sembarangan, karena ada alat untuk membaca Al-Qur’ān dengan baik dan benar, yang salah satunya adalah ilmu tajwid. Tidak sedikit orang yang membaca Al-Qur'ān masih terlihat terbata-bata, bahkan kurang memperhatikan panjang pendek bacaannya dan pengucapan hurufnya. Hal tersebut dikarenakan minimnya pengetahuan yang dimilikinya terkait ilmu tajwid. Dan misi dari MDTA Miftahussalam dalam meningkatkan kemampuan membaca Al-Qur'ān santrinya, jelas memberikan jalan bagi generasi muslim agar dimasa dewasanya lebih paham dan mampu membaca dan menulis AlQur'ān dengan benar, dan lebih efektif serta efisien.

2. Meningkatkan ilmu pengetahuan dīniyah Islāmiyah dan aqidah tauhid (DOK $\mathrm{A}$ ).

Ilmu pengetahuan diniyah seperti Al-Qur`ān, Al-Hadis̀, fiqih dan lain sebagainya, merupakan 
hal yang menjadi dasar pendidikan Islam yang harus dikembangkan oleh setiap muslim. Dengan mempelajari dan memahami ilmu pengetahuan dīniyah Islāmiyah, jelas akan meningkatkan dan memberikan bekal ilmu pengetahuan diniyah yang cukup kepada murid pada masa dewasa kelak. Semakin tinggi pengetahuan, wawasan dan pengalaman ilmu dīniyah Islāmiyah seseorang, aqidah tauhid pada diri seseorang pastinya akan semakin kuat. Dalam Islam, ilmu merupakan cahaya yang bisa memberikan petunjuk tentang baik dan buruk, benar dan salah, sedangkan aqidah dalam Islam adalah pondasi yang menempati posisi sentral dan tidak boleh diabaikan. Jika aqidah tauhid dianggap sebagai asal, ilmu pengetahuan dīniyah Islشmiyah dianggap sebagai rantingnya. Oleh sebab itu, keduanya adalah hal yang penting dan harus dimiliki oleh setiap muslim.

3. Melatih keterampilan dan kedisiplinan santri dalam mengamalkan amal ibadah (DOK A).

Perlu kita ketahui, bahwa disiplin dalam mengamalkan ibadah sangatlah penting. Apalagi jika hal tersebut dipupuk sejak usia dini, yang sangat memungkinkan tumbuh dan menjadi kebiasaan pada murid menjadi muslim yang istiqamah dalam mengamalkan amal ibadah. Muslim yang beriman, tidak sekedar percaya akan adanya Tuhan, melainkan berusaha mentaati segala perintah dan larangan-Nya, sampai pada titik taqwa (konsisten dalam pengamalan). Dan semua itu tidak akan datang dengan sendirinya, melainkan melalui latihan disiplin yang harus dilakukan secara terus menerus, hingga menjadi kebiasaan yang benar-benar terbiasa tanpa ada beban dan keterpaksaan. Dengan demikian, misi dari MDTA Miftahussalam terkait mendisiplinkan santrinya dalam mengamalkan amal ibadah merupakan salah satu upaya yang bisa menjadikan generasi muslim semakin istiqamah dalam beribadah, bahkan sampai pada tingkat taqwa.

4. Membiasakan berakhlak terpuji dan berjiwa Islami (DOK A).

Akhlaq mencakup dimensi yang luas, meliputi hubungan manusia dengan manusia, kepada Tuhannya, bahkan alam sekitarnya. Prioritas Nabi Muhammad saw. diutus ke bumi tidak lain untuk menyempurnakan akhlaq. Dan akhlaq menjadi sesuatu yang sangat penting untuk ditanamkan dan ditingkatkan khususnya pada generasi muslim saat ini. Menurut Tim Dosen PAI UPI (2009, hal. 153) akhlaq menyangkut masalah kehidupan yang berkaitan dengan ukuran baik buruk atau benar salahnya suatu perbuatan, dan perbuatan tersebut dapat berupa lahir maupun batin, baik menyangkut diri sendiri maupun orang lain. Tujuan pendidikan Islam salah satunya adalah mengembangkan potensi peserta didik agar berakhlaqul 
karimah. Begitupun tujuan dari lembaga pendidikan Islam, salah satunya adalah membina muridnya agar memiliki sikap terpuji. Dengan demikian, menjadikan generasi muslim yang berakhlaq terpuji dan berjiwa Islami adalah suatu keharusan bagi setiap lembaga pendidikan Islam. Karena akhlaq adalah perbuatan yang memang sudah tertanam dalam jiwa, dan selalu mendorongnya untuk berbuat baik, tanpa berfikir lama, lembaga pendidikan Islam memiliki tugas yang tidaklah mudah dalam mewujudkannya.

5. Membekali lulusan agar mampu berkompetisi secara sehat dan positif pada jenjang pendidikan yang lebih tinggi (DOK A).

Setiap lembaga pendidikan, mau tidak mau harus bersaing agar lulusannya menjadi paling unggul, baik dalam pengetahuan, wawasan maupun keterampilan. Mempersiapkan santri mampu mengikuti jenjang pendidikan madrāsah dīniyah yang lebih tinggi, sudah menjadi kewajiban bagi setiap madrāsah dīniyah. Hal ini sebagaimana tujuan dari pendidikan dīniyah salah satunya adalah menciptakan santri untuk dapat mengikuti jenjang pendidikan pada madrāsah dīniyah yang lebih tinggi (Departemen Agama Provinsi Jawa Tengah, 2009, hal. 8).

Sejalan dengan hal tersebut, misi dari pendidikan dīniyah tidak lain untuk meningkatkan mutu pendidikan melalui pengembangan sistem pembelajaran serta peningkatan sumber daya pendidik secara kuantitatif dan kualitatif (Departemen Agama Provinsi Jawa Tengah, 2009, hal. 7).

\section{Perencanaan Peningkatan Disiplin Ibadah Bagi Murid di Madrāsah Dīniyah Takmiliyah Awaliyah \\ Miftahussalam Kota Tegal}

Dalam perencanaan upaya peningkatan disiplin ibadah bagi murid di MDTA Miftahussalam, pihak madrāsah terlebih dahulu melakukan rapat musyawarah dengan melibatkan semua ustaż dan mualimah madrāsah. Perencanaan dilakukan dengan menyesuaikan visi dan misi madrāsah terlebih dahulu. Berdasarkan pengamatan pribadi ustaż atau mualimah, ketercapaian kedisiplinan murid dalam mengamalkan ibadah masih lemah. Adapun keluhan dari wali murid yang menginginkan anaknya tidak banyak bermain dan menonton televisi selesai șalāh magrib. Dengan demikian, pihak madrāsah mulai menentukan macam ibadah yang dianggap perlu ditingkatkan kedisiplinannya yaitu șalāh, żikir, berdo’a, Al-Qur`ān, As-Māul Ḥusna, dan șalawāh (WKM, WG 1- WG 5).

Semua ibadah yang telah disebutkan di atas, akan direalisasikan dalam program disiplin ibadah. Penentuan program disiplin ibadah disesuaikan dengan sumber daya (pendidik, pembimbing, pengawas) dan sarana pendukung (seperti Media dan tempat kegiatan) terlebih dahulu. Adapun program disiplin ibadah tersebut, pertama dengan pembiasaan sebelum Kegiatan Belajar Mengajar (KBM), yaitu membiasakan murid 
membaca As-Māul Husna, Al-Qur'ān, do'a harian dan șalawāh sebelum memulai kegiatan belajar mengajar. Kedua dengan mengadakan ekstrakurkuler pengajian dan șalāh jama'ah. Untuk ekstrakurikuler pengajian rutin dilakukan setiap bulan dan setiap datangnya Peringatan Hari Besar Islam (PHBI).

Sejalan dengan hal tersebut, merencanakan pada dasarnya menentukan kegiatan yang hendak dilakukan pada masa depan. Kegiatan ini dimaksudkan untuk mengatur berbagai sumber daya agar hasil yang dicapai sesuai dengan yang diharapkan (Fattah, 2011, hal. 49).

Tujuan dari upaya peningkatan disiplin ibadah bagi murid melalui beberapa disiplin ibadah tidak lain untuk melatih murid lebih terbiasa dan istiqamah beribadah, lebih berbekas dalam ibadahnya, menumbuhkan nilainilai ketauhidan. Diharapkan juga dapat memberikan kesadaran diri kepada murid bahwa ibadah merupakan kebutuhan kita sebagai seorang hamba (WKM, WG1 -WG6).

Sejalan dengan hal tersebut, Menurut Mc Kee dkk. (Lestari, 2012, hal. 63) bahwa pendisiplinan biasanya dilakukan agar anak dapat menguasai suatu kompetensi, melakukan pengaturan diri, dapat mentaati aturan, dan mengurangi perilaku-perilaku penyimpangan atau beresiko. Adapun tujuan ibadah menurut Nasution $\mathrm{H}$. (2013, hal. 31) yaitu membuat ruh manusia supaya senantiasa tidak lupa pada Tuhan, bahkan senantiasa dekat pada-Nya. Keadaan senantiasa dekat pada Tuhan dapat menjadi rem bagi hawa nafsu untuk melanggar nilai-nilai moral, peraturan, dan hukum yang berlaku dalam memenuhi keinginannya.

Jadi, dapat disimpulkan bahwa tujuan dari upaya peningkatan disiplin ibadah telah sesuai dengan beberapa teori di atas. Adanya disiplin ibadah tidak lain untuk menyadarkan murid menjalankan kewajibannya sebagai seorang hamba. Ketika disiplin ibadah telah tertanam pada diri murid, ruh pada dirinya akan senantiasa tidak lupa pada Tuhan, dan dapat menjadi rem bagi hawa nafsu untuk melanggar moral, peraturan dan hukum yang berlaku dalam memenuhi keinginannya. Dengan demikian, murid akan lebih bisa mengendalikan keinginan dan menjadikan ibadah sebagai kebutuhan tanpa merasa terancam oleh hukuman, serta perilaku baik akan muncul pada pribadinya.

Untuk meningkatkan disiplin ibadah bagi murid madrāsah, perangkat sangat diperlukan oleh ustaż dan mualimah guna memberikan kemudahan selama proses pelaksanaan. Dalam kamus Besar Bahasa Indonesia, dijelaskan bahwa perangkat adalah alat atau perlengkapan. Begitupun perencanaan terakhir yang dilakukan oleh pihak madrāsah, yaitu dengan membuat perangkat berupa buku kegiatan ibadah (Departemen Pendidikan dan Kebudayaan, 1991, hal. 752).

Perangkat yang dipersiapkan dalam meningkatkan disiplin ibadah bagi murid salah satunya yaitu buku Kegiatan Ibadah Șalāh Santri (KISS). Buku KISS berisi tentang ibadah șalāh lima waktu murid, yaitu șubuh, ḍuhur, așar, magrib dan isya. Ketika murid melaksanakan kelima șalāh wajib tersebut, murid akan memberi tanda 
ceklis dan meminta tanda tangan kepada orang tuanya (DOK 1, WG 1WG 5).

Selain buku KISS, pihak madrāsah juga menggunakan buku Kegiatan Ba'da Magrib (KBM) dan Buku Pembiasaan Akhlaq Santri (PAS). Buku KBM berisi tentang tadarus/ membaca Al-Qurān dan ta'lim/ belajar murid setiap hari, sedangkan untuk buku PAS berisi tentang żikir, berdo'a setelah șalāh, baca do'a sebelum dan sesudah makan (DOK 2, DOK 3, WKM, WG 1- WG 5). Semua hasil dari buku KISS, KBM dan PAS akan dimasukkan ke dalam buku raport yang nantinya akan diberikan kepada wali murid masingmasing (DOK R, WKM).

Ustaż dan mualimah sebagai pendidik di madrāsah, mendapatkan tugasnya masing-masing. Upaya peningkatan disiplin ibadah bagi murid MDTA Miftahussalam mengharuskan semua ustaż dan mualimah saling berinteraksi dan bekerjasama (WKM, WG 1, WG 2). Dalam pemberian nilai akhir, wali kelaslah yang paling bertanggung jawab. Meskipun demikian, semua ustaż dan mualimah ikut menyampaikan hasil penilaiannya kepada wali kelas masing-masing murid berdasarkan pengamatan objektif.

Sejalan dengan hal tersebut, Dalam sebuah organisasi setiap anggota akan mendapatkan tugas dan menjalankan tugas organisasinya dengan tanggung jawab penuh dan sesuai dengan kebijakan yang telah ditentukan. Untuk mewujudkan tujuan yang telah ditetapkan, sekelompok orang dalam organisasi tersebut juga harus saling berinteraksi, memberi, menerima dan saling bekerja sama (Siswanto, 2010, hal. 73). Dalam perencanaan minimal memiliki empat unsur sebagai berikut: a) adanya tujuan yang harus dicapai, b) adanya stategi untuk mencapai tujuan, c) sumber daya yang dapat mendukung, d) implementasi setiap keputusan (Sanjaya, 2011, hal. 24).

Dari pendapat Siswanto dan Sanjaya, dapat disimpulkan bahwa perencanaan yang dilakukan oleh pihak MDTA Miftahussalam disusun secara terstruktur dan sistematis, yaitu dengan menyesuaikan visi, misi dan tujuan madrāsah terlebih dahulu, yang kemudian menentukan beberapa macam ibadah. Selanjutnya pihak madrāsah menentukan program disiplin ibadah yang sesuai, dan dilanjutkan dengan tujuan dengan adanya upaya peningkatan disiplin ibadah bagi murid. Begitupun sumber daya dan sarana untuk pelaksanaan telah disesuaikan terlebih dahulu. Pihak madrāsah juga membuat perangkat yang akan digunakan untuk mengontrol disiplin ibadah bagi murid saat berada di luar lingkungan madrāsah.

Secara keseluruhan, waktu yang dibutuhkan selama perencanaan adalah satu Minggu. Rapat hanya dilakukan satu kali pertemuan, dan satu Minggu kemudian pihak madrāsah langsung merealisasikan semuanya. Selama proses perencanaan, ustaż dan mualimah selalu melakukan diskusi apabila ada kekurangan atau kendala (WKM, WG 1- WG 5). 


\section{Pelaksanaan Peningkatan \\ Disiplin Ibadah di Madrāsah \\ Dīniyah \\ Takmiliyah \\ Awaliyah \\ Miftahussalam \\ Kota Tegal}

Dalam meningkatkan disiplin ibadah, pihak madrāsah membuat beberaoa program disiplin ibadah. Pertama yaitu dengan membiasakan murid membaca As-Māul Husna, membaca Al-Qurān, do'a harian dan șalawāh nariyah sebelum memulai kegiatan belajar mengajar (WKM, WG 1- WG 5). Berdasarkan hasil observasi, membaca As-Māul Husna mencakup semua kelas. Untuk kelas 1, masih ada beberapa murid yang belum hafal dan membawa selembar fotokopi As-Māul Husna. Berbeda dengan kelas 2, 3 dan 4 yang secara keseluruhan sudah terlihat hafal dan lancar (O1- O6, O12, O13).

Untuk membaca do'a harian dan șalawāh nariyah hanya dibiasakan pada kelas 1 sebelum memulai kegiatan belajar mengajar. Adapun do'a yang dibaca seperti do'a sebelum dan sesudah makan, sebelum dan sesudah wudu, dll. Sedangkan do'a yang selalu dibaca pada setiap kelas yaitu do'a sebelum dan sesudah belajar (O1- O6).

Untuk pembiasaan membaca Al-Qurān sebelum memulai kegiatan belajar mengajar mencakup semua kelas. Namun, untuk pembagiannya berbeda yaitu kelas 1 hanya membaca surat-surat pendek dengan hafalan. Sedangkan untuk kelas 2, 3 dan 4, semuanya membaca Al-Qurān dengan mentartilnya bersama-sama. Ketika sedang diadakan Ujian Tengah Semester (UTS) dan Ujian Akhir Semester (UAS), Kelas 1 tetap membukanya dengan membaca suratsurat pendek. Berbeda dengan kelas 2, 3 dan 4 yang tidak membukanya dengan membaca Al-Qurān (O9, O10, WM 4, WM 5, WM 10).

Program disiplin ibadah ke dua yaitu ekstrakurikuler șalāh jama'ah, dengan beberapa kegiatan ibadah di dalamnya yaitu membaca șalawāh nariyah, șalāh aṣar berjama'ah, berdo'a dan berżikir (WKM, WG 1-5). Ekstrakurikuler șalāh jama'ah dilaksanakan di masjid Baitussalam, yang berjarak \pm 200 . Kegiatan diawali dengan berwudu terlebih dahulu, yang kemudian semua murid masuk ke dalam masjid dan bersama-sama membaca șalawāh nariyah.

Adapun bacaan dari șalawāh tersebut yaitu:

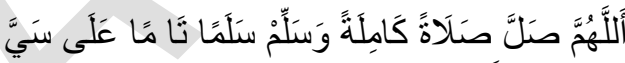

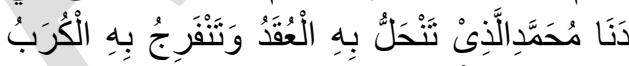

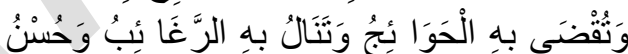

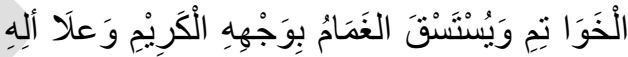

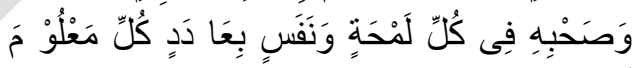
كَّك

Membaca șalawāh nariyah dilantunkan dengan suara lantang dan dinadomkan, dengan tujuan agar murid yang belum hafal cepat menghafal. Selanjutnya adalah melaksanakan șalāh așar berjama'ah yang dipimpin oleh salah satu guru madrāsah. Selama șalāh berlangsung, ada guru yang mengawasi dengan duduk di samping pintu depan masjid. Dengan adanya latihan dan pembiasaan șalāh, sangat memungkinkan menjadikan murid terbiasa dan tumbuh sikap disiplin diri dalam pelaksanaan șalāh, khususnya șalāh wajib secara berjama'ah.

Selesai șalāh, dilanjutkan dengan membaca żikir dengan cara 
berjama'ah. Adapun bacaan dari żikir tersebut yaitu:

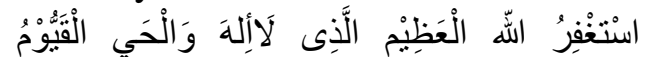

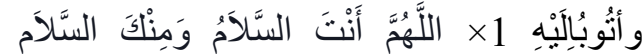

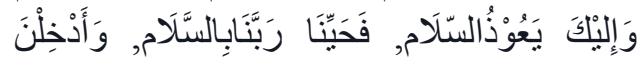

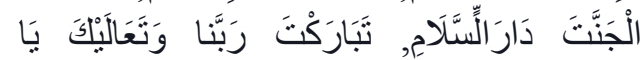

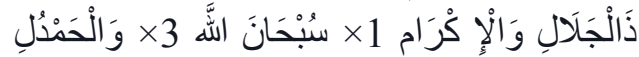

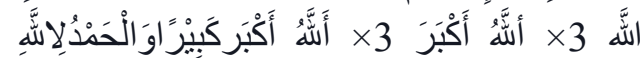

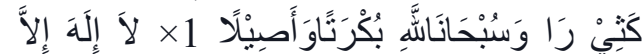

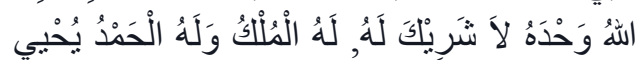

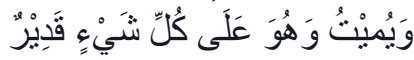

Terkait berżikir dengan cara berjama'ah, menurut Abdusshomad (2012, hal. 65) membaca żikir dengan cara berjama'ah setelah șalāh maupun Idalam momen tertentu seperti acara istigazah, tahilan dan lain-lain merupakan perbuatan yang tidak bertentangan dengan ajaran agama, bahkan termasuk perbuatan yang dituntun oleh agama. Sebagaimana dijelaskan dalam sebuah hadits:

"Dari Anas ra. ia berkata, Rasūl Allāh saw. bersabda: apabila kalian melewati taman surga, maka berżikirlah bersama mereka." Mereka bertanya: "Apa yang dimaksud taman surga wahai Rasūl Allāh?" Beliau menjawab: "kumpulan orang-orang yang berzikir." (HR. Ahmad)

Hadits tersebut menegaskan bahwa żikir yang dilakukan secara berjama'ah, termasuk setelah șalāh adalah boleh. Perbuatan tersebut tidak bertentangan dengan agama, dan termasuk dalam sunah nabĩ.. Adapun tujuan lain dari żikir dengan cara berjama'ah dan mengeraskan suara adalah agar murid yang masih belum hafal, menjadi hafal serta terbiasa mengamalkannya.
Selesai berżikir, dilanjutkan dengan berdo'a bersama-sama. Adapun bacaan dari do'a tersebut yaitu :

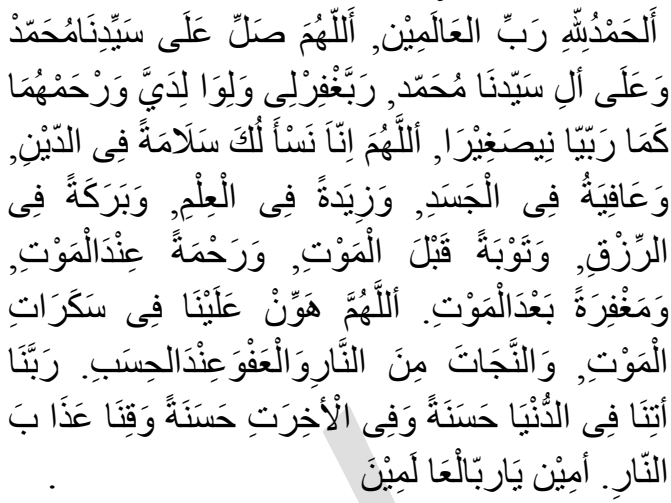

Program disiplin ibadah ketiga yaitu mengadakan ekstrakurikuler pengajian yang rutin diadakan setiap bulan dan setiap datangnya Peringatan Hari Besar Islam (PHBI) (WKM, WG 1). Pengajian bulanan dilaksanakan tepatnya hari Jumat, selesai ekstrakurikuler șalāh jama'ah di masjid Baitussalam. Setiap murid wajib hadir, bagitupun untuk murid yang sedang użur (terkena haid) ustaż dan mualimah mempersilahkannya berada di luar atau teras madrāsah. Pengajian diawali dengan menghadiahkan AlFātiḥạ̣ kepada Nabĩ Muhammad, keluarganya, sahabatnya, kepada para wali dan pendiri madrāsah (ustaż Sumar Maktubi). Selesai itu, dilanjutkan dengan żikir bersama yang dijaharkan (suara keras) (O7).

Żikir dipimpin oleh kepala madrāsah, yang kemudian diikuti oleh murid dan guru madrāsah. Hal ini berbeda dengan pembiasaan żikir ketika ekstrakurikuler șalāh jama'ah, dimana murid berżikir tanpa ada yang memimpin. Begitupun untuk bacaan żikir yang dibaca tidak sama seperti bacaan żikir yang dibaca selesai șalāh. Meskipun demikian, semua murid sudah terlihat hafal dan lancar. Selesai 
berżikir, dilanjutkan dengan ta'lim dengan penceramah ustaż Makmuri (kepala MDTA Miftahussalam) (O7).

Adapun pengajian Peringatan

Hari Besar Islam (PHBI) yang diadakan di dalam madrāsah, dan mengharuskan semua murid, ustaż dan mualimah hadir (kecuali yang berhalangan). Kegiatan diawali dengan bersama-sama melantunkan beberapa șalawāh yang diiringi dengan rebana, dan dilanjutkan dengan membaca AsMāul Husna, șalawāh nariyah serta do'a harian. Selanjutnya adalah ta'lim/ belajar dengan penceramah ustaż Makmuri selaku kepala MDTA Miftahussalam dan ustaż Baihaqi dari luar madrāsah (O11).

Semua program disiplin ibadah di atas merupakan sebuah kegiatan ibadah dengan pelatihan ibadah yang ditekankan pada pikiran dan kebiasaan. Menurut Lembaga Ketahanan Nasional (1997, hal.11) bahwa disiplin yang kaitannya dengan latihan yang memperkuat ditekankan pada pikiran dan watak untuk menghasilkan kendali diri, kebiasaan untuk patuh, dan sebagainya.

Upaya terakhir yaitu dengan membagikan semua buku disiplin ibadah yaitu Kegiatan Ibadah Śalāh Santri (KISS), Kegiatan Ba'da Magrib (KBM), dan Pembiasaan Akhlaq Santri (PAS). Hal ini dilakukan untuk mengontrol kedisiplinan ibadah șalāh, żikir, do'a harian, membaca Al-Qurān dan șalawāh oleh murid saat berada di luar lingkungan madrāsah (WKM, WG 1, WG 3-WG 5). Ustaż dan mualimah juga melakukan kerjasama dengan wali murid untuk mengontrol kegiatan anaknya saat berada di rumah. Ketiga buku disiplin ibadah harus dikumpulkan satu Minggu sebelum penerimaan buku raport, karena ustaż dan mualimah akan merekapitulasi nilai dari hasil penugasan buku tersebut ke dalam nilai di buku raport (WM 1- WM 11, WWM 1- WWM 6).

Semua upaya di atas selalu konsisten dilaksanakan oleh pihak MDTA Miftahussalam. Dengan demikian, diharapkan semua upaya disiplin ibadah yang diterapkan oleh pihak madrāsah telah menanamkan karakter disiplin ibadah yang jauh lebih baik. Selain itu, murid juga lebih terbiasa memiliki pengendalian dan penguasaan diri dalam urusan ibadah.

Dalam meningkatkan disiplin ibadah bagi murid, pihak madrāsah menggunakan beberapa metode. Metode pertama yaitu dengan pembiasaan. Hal ini berdasarkan temuan saat pelaksanaan, dimana pihak madrāsah selalu membiasakan murid membaca As-Māul Ḥusna, Al-Qurān, do'a harian dan șalawāh sebelum dimulainya kegiatan belajar mengajar. Selain itu, pihak madrāsah juga membiasakan murid melantunkan șalawāh, melaksanakan șalāh aṣar berjama'ah, żikir dan berdo'a pada ekstrakurikuler șalāh jama'ah, serta żikir dan berdo'a pada ekstrakurikuler pengajian (WKM, O1- O13).

Pembiasaan yang dilakukan oleh pihak madrāsah sangat berperan penting dalam meningkatkan disiplin ibadah murid. Sebagaimana menurut Prijosaksono \& Sanjaya (Hariyanto, 2010) sikap disiplin akan tumbuh apabila sering dilakukan secara berulang-ulang dan terus menerus secara berkesinambungan. Suatu tindakan yang dilakukan secara konsisten dan berkesinambungan akan 
menjadi suatu kebiasaan yang mengarah pada tercapainya keunggulan.

Metode kedua yaitu dengan memberikan hukuman dan penghargaan. Ada dua hukuman yang sering diberikan oleh pihak madrāsah kepada murid yang melakukan pelanggaran. Apabila ada murid yang bercanda atau mengobrol saat sedang membaca Al-Qurān bersama, murid yang bersangkutan akan mendapat hukuman yaitu kembali membaca surat yang baru saja dibaca (WKM, WG 2). Adapun ketika șalāh aṣar berlangsung dan ada murid yang bercanda, murid yang bersangkutan akan mendapat hukuman yaitu șalāh kembali dari takbir sampai salam, atau membaca istigfar dengan dijaharkan (WKM, WG 1- WG 5).

Hukuman lain untuk murid yang malas beribadah, baik dari pengamatan setiap guru, penilaian teman dan hasil dari buku disiplin ibadah yang telah dibagikan adalah pengurangan nilai pada buku raport. Apabila murid susah untuk mengikuti kegiatan disiplin ibadah, hukuman yang diberikan adalah dengan memngaggil wali murid yang bersangkutan (WKM, WG 1- WG 5). Ketika pemanggilan wali murid tidak memberikan perubahan, pihak madrāsah tidak menaikkan kelas murid tersebut (WKM, WG 1- WG 3, WG 5). Semua hukuman yang diterapkan oleh pihak madrāsah, tidak lain sebagai pembinaan agar murid tidak mengulangi perbuatan yang sama (dilanggar). Dengan demikian, pelanggaran yang dilakukan oleh murid dapat diminimalisir, bahkan dihilangkan. Yang kemudian, tumbuh sikap taat dan tertib pada aturan yang telah dibuat, tanpa adanya keterpaksaan pada pribadi murid dalam pelaksanaan. Sehingga sikap disiplin khususnya dalam pelaksanaan amal ibadah, akan lebih konsisten.

Menurut Hurlock (1978, hal. 87) hukuman mempunyai tiga peran penting dalam perkembangan moral anak, yaitu (1) menghalangi pengulangan tindakan yang tidak diinginkan oleh masyarakat, (2) mendidik anak membedakan besar kecilnya kesalahan yang diperbuat mereka, (3) memberi motivasi untuk menghindari perilaku yang tidak diterima oleh masyarakat. Dalam dunia pendidikan, punishment sangat diperlukan karena dua hal, yaitu: (1) hukuman diadakan karena ada pelanggaran dan adanya kesalahan yang diperbuat, (2) hukuman diadakan dengan tujuan agar tidak terjadi pelanggaran (Ramayulis, 2012, hal. 303-304).

Selain hukuman, adapun penghargaan yang diberikan kepada murid saat kegiatan berlangsung berupa pujian dan beberapa perlengkapan sekolah dari ustaż ataupun mualimah. Begitupun ketika kenaikan kelas, murid yang terlihat rajin baik dari pengamatan setiap guru, teman dan buku disiplin ibadah yang telah dibagikan akan mendapatkan hadiah berupa trophy dan beberapa perlengkapan sekolah (WKM, WG 1WG 5, WM1- WM 3, WM 5- WM 7, WM 9- WM 11). Hadiah berupa perlengkapan sekolah menggunakan dana sumbangan dari ustaż dan mualimah MDTA Miftahussalam (WKM, WG 5). 
Menurut Hurlock (1978, hal. 90) penghargaan mempunyai tiga peran, yaitu (1) mempunyai nilai mendidik, terlihat apabila tindakan yang dilakukan itu disetujui, anak merasa bahwa itu baik, (2) sebagai motivasi untuk mengulangi perilaku yang disetujui secara sosial, (3) memperkuat perilaku yang disetujui secara sosial, dan tiadanya penghargaan melemahkan keinginan untuk mengulang perilaku ini.

Berdasarkan hasil observasi, peneliti menemukan penghargaan berupa pujian yang diberikan oleh ustaż dan mualimah saat berlangsungnya ekstrakurikuler șalāh jama'ah. Pujian tersebut disampaikan baik secara personal, maupun dengan menjadikan murid yang disiplin beribadah sebagai contoh untuk memotivasi murid lainnya (O3, O5, O8, O13).

Sejalan dengan hal tersebut, menurut Hurlock (1978, hal 90) penghargaan tidak harus berbentuk materi, tetapi dapat berupa kata-kata pujian, senyuman atau tepukan dipunggung.

Berdasarkan penjelasan di atas, peneliti juga menyimpulkan bahwa dalam pelaksanaannya pihak MDTA Miftahussalam menggunakan metode demokratis. Hal tersebut berdasarkan hukuman dan penghargaan yang diberikan pihak madrāsah kepada murid yang bersifat edukatif. Sebagaimana menurut Hurlock (1978, hal. 93-94) metode demokratis menggunakan penjelasan dalam membantu anak mengerti perilaku yang diharapkan, dengan menggunakan hukuman dan penghargaan yang menekankan pada aspek edukatif, namun lebih menekankan penghargaan. Tujuan disiplin demokratif adalah mengajar anak mengembangkan kendali atas perilaku mereka akan melakukan apa yang benar meski tidak ada hukuman yang mengancam mereka.

Selain metode di atas, ustaż dan mualimah MDTA Miftahussalam juga sering memberikan motivasi kepada murid. Hal tersebut bertujuan memberi dorongan agar murid bertambah semangatnya dan disiplin beribadah. Ustaż dan mualimah sering memberikan motivasi kepada murid agar selalu mengamalkan ilmunya seperti mendirikan șalāh lima waktu dan rajin membaca Al-Qurān. Pemberian motivasi tidak dijadwalkan secara khusus, karena kapan dan dimanapun ustaż dan mualimah bisa menyampaikannya, seperti ketika kegiatan belajar mengajar berlangsung, ekstrakuriuler pengajian dan șalāh jama'ah (WKM, WG 1, WG 4, O2, O3, O8, O13).

Dalam dunia pendidikan, motivasi sangat diperlukan dalam setiap pencapaian tujuan. Menurut Agustin (2011, hal. 24-25) ada beberapa strategi yang digunakan agar murid lebih termotivasi, yang diantaranya yaitu memberikan hadiah, pujian, hukuman dan membangkitkan dorongan kepada murid. Adapun menurut Azhari (2004, hal. 56-67) motivasi tidak dapat dipisahkan dari kebutuhan seseorang sebagai organisme yang hidup dalam melakukan suatu perbuatan. Setidaknya motivasi berhubungan dengan kebutuhan. Motivasi jelas memiliki pengaruh pada tingkah laku seseorang. Ia dapat menjadi 
pendorong, pemberi semangat untuk maraih sesuatu yang diinginkan dan dicita-citakan, bisa jadi pemelihara agar orang tidak mudah putus asa.

Jadi, ada 3 metode yang digunakan oleh pihak madrāsah dalam meningkatkan disiplin ibadah bagi murid yaitu dengan metode pembiasaan, demoktatif (penghargaan dan hukuman yang bersifat edukatif), dan motivasi.

Selama pelaksanaan, pihak madrāsah juga menggunakan beberapa media. Salah satu media yang sering digunakan yaitu alat pengeras suara (mikrofon dan speaker). Alat pengeras suara digunakan saat membaca AsMāul Husna, do'a harian dan surat pendek sebelum memulai kegiatan belajar mengajar di kelas 1 dan saat diadakannya pengajian Peringatan Hari Besar Islam (PHBI). Media lain yang selalu ada di dalam kelas yaitu gambar praktek șalāh dan hadis yang tertulis pada dinding dan jendela kelas (WKM, WG 1- WG 5, O 2).

Sejalan dengan hal tersebut, bahwa media yang berkaitan dengan suara tergolong dalam media uadio. Sebagaimana menurut Brets (Ibrahim \& Syaodih, N, 2003, hal. 114) bahwa media audio adalah media yang hanya menggunaan suara seperti radio, telepon, audio tipe dan lain-lain.

Selain media di atas, pihak madrāsah juga menggunakan media cetak yaitu fotokopian As-Māul Ḥusna, kitab Al-Qurān, juz 'amma dan buku do'a harian. Untuk Al-Qurān, pihak madrāsah memang telah menyediakannya. Namun untuk juz 'amma dan buku do'a harian, murid membawanya sendiri dari rumah (WKM, WG 1- WG 5, O2, O10, O11).
Sebagaimana menurut Ibrahim \& Syaodih (2003, hal. 115) media cetak adalah bahan yang diproduksi melalui percetakan profesional seperti buku, majalah, dan modul. Sebenarnya disamping itu masih ada bahan lain yang juga dapat digolongkan ke dalam istilah "cetak", seperti tulisan, bagan, fotokopi ataupun hasil reproduksi sendiri.

Dalam Islam, disiplin ibadah sangat diperlukan bagi seorang hamba guna memberikan berbagai latihan rohani. Madrāsah sebagai lembaga pendidikan Islam pastinya berusaha menciptakan suasana atau iklim yang positif. Adapun suasana yang ingin diciptakan di MDTA Miftahussalam dengan adanya upaya peningkatan disiplin ibadah yaitu suasana yang religius (WKM, WG 1- WG 5).

Menurut Muhaimin (2009, hal. 61) religius berarati sifat religi atau keagamaan, atau yang bersangkut paut dengan religi (keagamaan). Penciptaan suasana religius berarti menghidupkan suasana atau iklim kehidupan keagamaan. Sejalan dengan pendapat Muhaimin, Nata (2012, hal. 44) berpendapat bahwa religi atau agama Islam dapat diartikan sebagai tujuan jangka panjang, cita-cita masa depan, dan impian ideal yang ingin diwujudkan oleh pendidikan Islam.

Berdasarkan teori di atas, suasana religius telah berhasil diciptakan oleh pihak MDTA Miftahussalam. Hal ini dapat dilihat dengan terciptanya suasana kehidupan keagamaan. Banyaknya kegiatan ibadah juga menjadi faktor penting terwujudnya suasana religius di lingkungan MDTA Miftahussalam. 
4. Hasil Peningkatan Disiplin Ibadah Bagi Murid di Madrāsah Dīniyah Takmiliyah Awaliyah Miftahussalam Kota Tegal

a. Teknik dan Waktu Evaluasi Peningkatan Disiplin Ibadah Bagi Murid di MDTA Miftahussalam

Untuk memperoleh data dan hasil dari upaya peningkatan disiplin ibadah bagi murid, pihak madrāsah menggunakan teknik evaluasi. Beberapa teknik evaluasi tersebut yaitu:

1. Pengamatan pribadi ustaż dan mualimah kepada setiap murid. Teknik evaluasi pertama yaitu dengan melakukan pengamatan yang dilakukan oleh ustaż dan mualimah kepada masingmasing murid, baik saat berada di dalam maupun luar lingkungan madrāsah. Pengamatan yang dilakukan saat berada di lingkungan madrāsah seperti perilaku/ akhlaq murid, dan keikutseraan murid dalam setiap kegiatan ibadah. Sedangkan pengamatan yang dilakukan saat berada di luar lingkungan madrāsah sering kali hanya dilakukan oleh ustaż dan mualimah yang rumahnya dekat dengan murid. Sejalan dengan hal tersebut, menurut BSNP dalam buku Evaluasi Pembelajaran Prinsip dan Teknik Prosedur, teknik observasi atau pengamatan, yaitu teknik yang dilakukan secara formal maupun informal instrument. Secara formal, observasi dilakukan dengan instrument yang sengaja dirancang, sedangkan secara informal observasi dilakukan oleh pendidik tanpa menggunakan instrument (Arifin Z. , 2014, hal. 60).

2. Menanyakan kepada teman sejawat.

Evaluasi lain yang dilakukan oleh ustaż dan mualimah MDTA Miftahussalam adalah dengan menanyakan beberapa hal kepada teman sejawat. Pertanyaan yang sering disampaikan kepada murid terkait temannya adalah bagaimana șalāh temannya dan kebiasaan ba'da magrib temannya. Terkadang teman murid juga ada yang menyampaikan keluhan atau melaporkan kebiasaan jelek temannya kepada ustaż atau mualimah.

Sejalan dengan hal tersebut, menurut BSNP dalam buku Evaluasi Pembelajaran Prinsip dan Teknik Prosedur, penilaian antar teman adalah teknik yang dilakukan dengan meminta peserta didik mengemukakan kelebihan dan kekurangan teman dalam berbagai hal. Penilaian ini dapat pula berupa sosiometri untuk mendapat informasi anak-anak yang favorit dan anak-anak yang terisolasi dalam kelompoknya (Arifin Z. , 2014, hal. 61).

3. Penugasan buku disiplin ibadah bagi murid. Setiap murid ditugaskan oleh ustaż dan mualimah untuk melaksanakan seluruh ibadah 
yang tercantum dalam buku disiplin ibadah dan mengisinya. Adapun ketiga buku tersebut yaitu Kegiatan Ibadah Șalāh Santri (KISS), Kegiatan Ba'da Magrib (KBM) dan Pembiasaan Akhlaq Santri (PAS). Buku diisi dengan kejujuran, baik oleh murid maupun wali murid, yang selanjutnya ditandatangani oleh wali murid yang bersangkutan. Hasil dari buku kegiatan disiplin ibadah akan dimasukkan kenilai buku raport yaitu pada kolom nilai prestasi baca tulis Al-Qur'ān, ekstrakurikuler pengajian dan șalāh jama'ah, serta kepribadian.

Teknik yang dilakukan oleh ustaż dan mualimah dapat disimpulkan termasuk dalam teknik penugasan. Hal ini sebagaimana menurut BSNP dalam buku Evaluasi Pembelajaran Prinsip dan Teknik Prosedur, penugasan adalah teknik evaluasi yang dapat dilakukan dengan model proyek yang berupa sejumlah kegiatan yang dirancang, dilakukan dan diselesaikan oleh peserta didik di luar kegiatan kelas dan harus dilaporkan baik secara tertulis maupun lisan (Arifin Z. , 2014, hal. 60).

Sehingga dapat disimpulkan bahwa dalam memberikan penilaian, pihak madrāsah menggunakan 3 teknik evaluasi yaitu teknik observasi atau pengamatan, teknik penilaian antar teman, dan teknik penugasan. Semua hasil dari penilaian tersebut, akan dihitung oleh wali kelas dan dimasukkan ke dalam buku raport. Penilaian disiplin membaca Al-Qur`ān murid dimasukkan ke dalam kolom nilai prestasi baca tulis Al-Qur’ān, sedangkan penilaian șalāh, żikir, șalawāh, dan keikutsertaan murid dalam ekstrakurikuler pengajaan dan șalāh jama'ah, secara keseluruhan dimasukkan ke dalam kolom nilai ektrakurikuler pengajian dan șalāh jama'ah. Untuk murid yang disilplin mengamalkan do'a harian akan diberikan tambahan nilai pada kepribadian dan mata pelajaran yang dianggap pantas.

Waktu evaluasi yang dilakukan oleh pihak MDTA Miftahussalam adalah setiap hari, bulan dan semester. Evaluasi harian dilakukan apabila terjadi pelanggaran yang dilakukan oleh murid, yang kemudian ustaż dan mualimah berdiskusi untuk mencari jalan keluarnya. Selain itu, ustaż dan mualimah juga sering melakukan evaluasi setiap bulan dengan mengikutsertakan semua ustaż dan mualimah, untuk membahas beberapa hal seperti perkembangan dan kendala selama pelaksanaan, yang selanjutnya mencari jalan keluar.

Berdasarkan hal tersebut, evaluasi setiap hari dan bulan yang dilakukan oleh pihak madrāsah termasuk dalam evaluasi formatif. Dengan evaluasi tersebut, pihak madrāsah akan mendapatkan informasi selama proses berjalannya program, khususnya untuk perbaikan program apabila ada kekurangan. Sebagaimana menurut Westom, MC Alpine dan Bordonaro menjelaskan bahwa tujuan evaluasi formatif adalah untuk memastikan tujuan yang diharapkan 
dapat tercapai dan untuk melakukan perbaikan suatu produk atau program. Adapun menurut Worthen dan Sandres bahwa evaluasi formatif dilakukan untuk memberikan informasi evaluatif yang bermanfaat untuk memperbaiki program (Badrujaman, 2011, hal. 4344).

$\begin{array}{lrr}\text { Untuk } & \text { evaluasi } & \text { semester } \\ \text { pertahun, } & \text { dilakukan } & \text { dengan } \\ \text { mengadakan } & \text { rapat } & \text { dan }\end{array}$

mengikutsertakan semua guru guna membahas semua program disiplin ibadah yaitu pembiasaan sebelum kegiatan belajar mengajar, ekstrakurikuler pengajian dan șalāh jama'ah. Selain itu, ustaż dan mualimah juga mempertimbangkan hasil pengisian murid pada buku Kegiatan Ibadah Șalāh Santri (KISS), Kegiatan Ba'da Magrib (KBM) dan Pembiasaan Akhlaq Santri (PAS) untuk memberikan penilaian pada masing-masing murid. Dengan demikian, pihak madrāsah mendapatkan gambaran terkait hasil perkembangan disiplin ibadah pada setiap murid.

Berdasarkan hal tersebut, peneliti menyimpulkan bahwa jenis evaluasi yang dilakukan pada setiap semester/ tahun oleh pihak madrāsah termasuk dalam evaluasi sumatif. Sebagaimana menurut (Badrujaman, 2011, hal. 48) evaluasi sumatif merupakan evaluasi yang menilai hasil program atau akibatnya. Untuk menentukan efektifitas program, maka evaluasi perlu dilakukan untuk mengetahui sejauh mana capaian hasil. Untuk mengetahui hal tersebut, beberapa informasi dapat digunakan dalam evaluasi sumatif, baik informasi sebelum program diselenggarakan maupun informasi setelah program diselenggarakan.

b. Hasil Ketercapaian Peningkatan Disiplin Ibadah Bagi Murid di MDTA Miftahussalam

Berdasarkan hasil evaluasi guru, peningkatan disiplin ibadah murid menunjukkan konsistensinya baik ketika berada di dalam maupun luar lingkungan madrāsah mencapai 90\%. Hal tersebut berdasarkan antusias murid dalam mengikuti beberapa kegiatan ibadah saat berada di lingkungan madrāsah, pengamatan guru kepada murid saat berada di dalam maupun luar lingkungan madrāsah dan hasil dari buku disiplin ibadah murid (WKM, WG 1- WG 5).

Sejalan dengan hal tersebut, Siswanto (2010, hal. 101) mengemukakan bahwa evaluasi dirancang untuk mencapai kesimpulan yang dapat memberikan pertimbangan mengenai hasil karya tersebut serta unuk mengembangkan karya tersebut melalui program. Adapun menurut Stufflebeam (Arikunto \& Jabar, 2009, hal. 1-2) bahwa dengan evaluasi, kita dapat mengetahui perubahan pada pribadi siswa.

Jika dilihat dari tujuan evaluasi menurut Siswanto dan Stufflebeam, dapat disimpulkan bahwa evaluasi yang dilakukan oleh pihak madrāsah yaitu untuk mengetahui sejauh mana peningkatan disiplin ibadah murid dan menjadi acuan dalam meningkatkan mutu disetiap kegiatan yang akan dilaksanakan di kemudian hari.

$$
\text { Hasil wawancara yang }
$$
dilakukan peneliti kepada murid dan wali murid, menunjukkan konsistensi ibadah murid saat berada di luar 
lingkungan madrāsah yaitu șalāh, żikir, do'a harian, membaca Al-Qur'ān dan șalawāh (WM 1-WM 11, WWM 1WWM6). Untuk berżikir dengan membaca As-Māul Ḥusna, beberapa murid mengaku jarang mengamalkannya (WM 3, WM 4, WM 6, WM 8, WM 11, WWM 1, WWM 4). Adapun hasil dari analisis dokumen berupa buku disiplin ibadah beberapa murid menunjukkan konsistensi ibadah yang dilakukan keseharian murid, yaitu șalāh lima waktu, żikir, do'a harian dan membaca Al-Qur’ān (O14).

Jadi, hasil ketetercapaian disiplin ibadah murid telah menunjukan keberhasilan dan kekurangan yang apabila dipersentase mencapai 90\%. Keberhasilan dapat dilihat dari konsistensi ibadah keseharian murid yaitu șalāh, żikir, do'a harian, membaca Al-Qur'ān, dan șalawāh yang murid lakukan, sedangkan untuk kekurangan dapat dilihat dari masih adanya murid yang jarang berżikir dengan membaca AsMāul Husna. Meskipun demikian, kedisiplinan ibadah murid dalam pelaksanaan ibadah șalāh, żikir, do'a harian, membaca Al-Qur'ān, dan șalawāh mengalami peningkatan yang jauh berbeda sebelum murid belajar di MDTA Miftahussalam.

\section{KESIMPULAN}

Berdasarkan hasil analisis dan pembahasan, secara umum dapat disimpulkan bahwa upaya peningkatan disiplin ibadah bagi murid di Madrāsah Dīniyah Takmiliyah Awaliyah Miftahussalam yaitu melalui pembiasaan, hukuman dan penghargaan yang bersifat mendidik, serta motivasi. Secara keseluruhan, upaya yang dilakukan oleh pihak madrāsah cukup baik, baik dari segi perencanaan, pelaksanaan dan hasil evaluasi. Adapun secara terperinci, upaya peningkatan disiplin ibadah bagi murid di MDTA Miftahussalam Kota Tegal adalah sebagai berikut :

1. Profil MDTA Miftahussalam Kota Tegal terdiri dari sejarah bangunan, visi, misi, strategi dan tujuan serta sasaran. MDTA Miftahussalam Kota Tegal berdiri pada tahun 1974 atas tanah wakaf, dimana dilatarbelakangi oleh banyaknya warga setempat yang menginginkan tempat pendukung untuk belajar agama/ mengaji anak-anaknya di ustaż Sumar Maktubi (selaku pendiri).

2. Perencanaan dalam upaya peningkatkan disiplin ibadah bagi murid di MDTA Miftahussalam Kota Tegal adalah disusun secara sitematis dengan menyesuaikan visi, misi dan tujuan madrāsah terlebih dahulu. Karena kedisiplinan ibadah murid dirasa masih kurang, dibuatlah program disiplin ibadah yaitu (a) pembiasaan membaca As-Māul Husna, do'a harian, membaca AlQur'ān dan șalawāh sebelum memulai kegiatan belajar mengajar, (b) ekstrakurikuler pengajian dan șalāh jama'ah. Adapun tujuan yang telah dirumuskan yaitu melatih murid lebih terbiasa dan istiqamah beribadah, lebih berbekas dalam ibadahnya, dan menumbuhkan nilai-nilai ketauhidan. Diharapkan juga dapat memberikan kesadaran 
diri kepada murid bahwa ibadah merupakan kebutuhan kita sebagai seorang hamba.

Perangkat yang digunakan dalam mengontrol disiplin ibadah murid yaitu (a) buku Kegiatan Ibadah Șalāh Santri (KISS), (b) buku Kegiatan Ba'da Magrib (KBM), (c) buku Pembiasaan Akhlaq Santri (PAS). Untuk penilaian akhir, pihak madrāsah akan memasukkan hasil dari ketiga perangkat di atas ke dalam buku raport. Waktu yang dibutuhkan selama perencanaan yaitu satu Minggu,

3. Pelaksanaan dari upaya peningkatan disiplin ibadah bagi murid di MDTA Miftahussalam Kota Tegal adalah melalui program disiplin ibadah. Berdasarkan hasil data yang diperoleh, pelaksanaan telah dilakukan dengan baik, terjadwal dan konsisten. Pertama, dengan membiasakan murid membaca AsMāul Ḥusna, membaca Al-Qur'ān, do'a dan berșalawāh sebelum memulai kegiatan belajar mengajar. Setiap kelas mendapat bagian masing-masing, yaitu kelas 1 sebelum memulai kegiatan belajar mengajar dengan membaca As-Māul Ḥusna, Al-Qur ān berupa surat-surat pendek, do'a harian dan șalawāh nariyah. Sedangkan untuk kelas 2, 3 dan 4, sebelum kegiatan belajar mengajar memulainya dengan membaca AsMāul Ḥusna, Al-Qur'ān dan do'a sebelum belajar.

Kedua dengan mengadakan ekstrakurikuler șalāh jama'ah yang diikuti oleh kelas 1, 2, 3, dan 4 pada waktu șalāh aśar, kecuali untuk murid yang berhalangan seperti terkena haid. Macam ibadah yang direalisasikan pada ekstrakurikuler șalāh jama'ah yaitu șalawāh, șalāh, berżikir dan berdo'a.

Ketiga dengan mengadakan pengajian bulanan dan setiap datangnya Peringatan Hari Besar Islam (PHBI) yang diikuti oleh semua murid madrāsah, kecuali bagi murid yang berhalangan hadir. Ibadah yang ada pada ekstrakurikuler pengajian bulanan adalah berżikir dan ta'lim. Sedangkan ibadah yang dilakukan saat PHBI yaitu membaca AsMāul Ḥusna, melantunkan șalawāh nariyah, membaca beberapa do'a harian.

Keempat dengan membagikan buku Kegiatan ibadah Șalāh Santri (KISS), Kegiatan Ba'da Magrib (KBM) dan Pembiasaan Akhlaq Santri (PAS) sebagai penugasan dan pengontrol disiplin ibadah murid saat berada di luar lingkungan madrāsah..

Metode yang digunakan oleh pihak madrāsah dalam upaya peningkatan disiplin ibadah bagi murid yaitu metode pembiasaan, metode demoktratis (hukuman dan penghargaan yang bersifat edukatif) dan motivasi. Selain itu, pihak madrāsah menggunakan media pendukung seperti alat pengeras suara (speaker dan mikrofon), gambar praktek șalāh, hadis yang tertulis pada dinding dan jendela depan kelas, kitab suci Al-Qur'ān, juz 'amma dan buku do'a harian. 
4. Untuk menentukan hasil dari upaya peningkatan disiplin ibadah bagi murid, pihak madrāsah menggunakan teknik evaluasi. Berdasarkan data, ada 3 teknik evaluasi yang digunakan yaitu teknik observasi/ pengamatan, teknik penilaian antar teman dan teknik penugasan. Waktu evaluasi yag dilakukan yaitu setiap hari, setiap bulan dan semester/ tahun. Berdasarkan hasil evaluasi oleh guru dan wawancara yang dilakukan peneliti menunjukkan konsistensi ibadah keseharian murid saat berada di luar lingkungan madrāsah yang mencapai $90 \%$ yaitu șalāh, żikir, do'a harian, membaca Al-Qur'ān dan șalawāh. Sedangkan berżikir dengan membaca As-Māul Ḥusna, beberapa murid mengaku jarang melaksanakannya. Hasil analisis dokumen yang peneliti lakukan menunjukkan disiplin ibadah keseharian murid yang berkelanjutan yaitu șalāh lima waktu, żikir, do'a harian dan membaca Al-Qur’ān.

\section{DAFTAR PUSTAKA}

Abdusshomad, M. (2012). Hujjah NU Akidah-Amaliah-Tradisi.

Surabaya: Khalista.

Aftiani, H. (2013). Penerapan Konseling Kelompok Behavior Untuk Meningkatkan Kedisiplinan Siswa di Sekolah SMAN 1 Kedungadem Bojonegoro. BK UNESA, 3(2), 437-444.
Agustin, M. (2011). Permasalahan Belajar dan Inovasi Pembelajaran: Panduan Untuk Guru, Konselor, Psikolog, Orang Tua, dan Tenaga Kependidikan. Bandung: Reflika Aditama.

Arifin, Z. (2014). Evaluasi Pembelajaran Prinsip dan Teknik Prosedur. Bandung: Remaja Rosdakarya.

Arifin, Z. (2014). Penelitian Pendidikan; Metode dan Paradigma Baru. Bandung: PT. Remaja Rosdakarya.

Arikunto, S., \& Jabar, S. A. (2009). Evaluasi Program Pendidikan. Jakarta: Bumi Aksara.

Azhari, A. (2004). Psikologi Umum dan Perkembangan. Jakarta: Teraju.

Badrujaman, A. (2011). Teori dan Aplikasi Evaluasi Program Bimbingan Konseling. Jakarta: Indeks.

Creswell, J. W. (2013). Research Design; Pendekatan Kualitatif, Kuantitatif dan Mixed. (A. Fawaid, Trans.) Yogyakarta: Pustaka Pelajar.

Departemen Agama Provinsi Jawa Tengah. (2009). Panduan Kurikulum dan Standar Pelayanan Minimal Madrasah Diniyah Tingkat Ula. Semarang: Kantor Departemen Agama Provinsi Jawa Tengah.

Departemen Pendidikan dan Kebudayaan. (1991). Kamus 
Besar Bahasa Indonesia. Jakarta: Balai Pustaka.

Fattah, N. (2011). Landasan Manajemen Pendidikan . Bandung: Remaja Rosdakarya.

Fiani, F. Z., Daharnis, \& Ridha, M. (2013). Disiplin Siswa Disekolah dan Implikasinya dalam Pelayanan Bimbingan dan Konseling. Ilmiah Konseling, 2(23), 26-33.

Ghazali, D. A., \& Gunawan, H. (2015). Studi Islam: Suatu Pengantar dengan Pendekatan Interdisipliner. Bandung: PT Remaja Rosdakarya.

Hariyanto. (2010, Agustus 25). Menumbuhkan Sikap Disiplin Diri. Retrieved Maret 9, 2016, from Belajarpsikologi Web site:

http://www.belajarpsikologi.co $\mathrm{m}$

Hurlock, E. B. (1978). Perkembangan Anak Jilid 2. (M. M. Tjandrasa, Trans.) Jakarta: Erlangga.

Ibrahim \& Syaodih, N. (2003). Perencanaan Pengajaran. Jakarta: Asdi Mahasatya.

Lembaga Ketahanan Nasional. (1997). Disiplin Nasional. Jakarta: PT. Balai Pustaka.

Lestari, S. (2012). Psikologi Keluarga; Penanaman Nilai dan Penanganan Konflik dalam Keluarga. Jakarta: Kencana.

Muhaimin. (2009). Pengembangan Kurikulum Pendidikan Agama
Islam di Sekolah, Madrasah, dan Perguruan Tinggi. Jakarta: Rajawali Pers.

Mulyasa. (2010). Kurikulum Berbasis Kompetensi; Konsep Karakteristik, dan Implementasi. Bandung: PT. Remaja Rosdakarya.

Nasution. (2009). Metode Research ; penelitian ilmiah. Jakarta : Bumi Aksara.

Nasution, H. (2013). Islam Ditinjau Dari Berbagai Aspeknya. Jakarta: Universitas Indonesia.

Nata, A. (2012). Ilmu Pendidikan Islam. Jakarta: Kencana Prenada Media Group.

Nazir, M. (2011). Metode Penelitian. Bogor: Ghalia Indonesia.

Pujawati, Z. (2016). Hubungan Kontrol Diri dan Dukungan Orang Tua dan Perilaku DIsiplin Pada Santri di Pondok Pesantren Darussa'adah Samarinda. Psikologi, 4(2), 227-236.

Ramayulis. (2012). Ilmu Pendidikan Islam. Jakarta: Kalam Mulia.

Sanjaya, W. (2011). Perencanaan dan Desain Sistem Pembelajaran. Jakarta: Prenada Media Group.

Siswanto. (2010). Pengantar Manajemen. Jakarta: Bumi Aksara.

Sumarya, D., \& Nuryani, P. (2010). Landasan Pendidikan. Bandung: Sub Koordinator 
MKDP Landasan Pendidikan UPI.

Syahidin. (2009). Menelusuri Metode Pendidikan dalam Al-Quran. Bandung: Alfabeta.

Tim Dosen PAI UPI. (2009). Islam Tuntunan dan Pedoman Hidup. Bandung: Value Press.
Usman, H. (2010). Managemen Teori, Praktik dan Riset Pendidikan. Jakarta: Bumi Kasara. 